\author{
Patrycja Lisiecka, Dagmara Piątkowska \\ Gimnazjum nr 20 w Gdańsku; PSOUU KOŁO w Świdnicy \\ Ośrodek Rehabilitacyjno-Edukacyjno-Wychowawczy
}

\title{
Wpływ wad zgryzu na zaburzenia artykulacji
}

\section{Wstęp}

Zależność pomiędzy wadami zgryzu a zaburzeniami artykulacji jest niezaprzeczalna. Istotne jest znalezienie odpowiedzi na pytanie, jakie wady zgryzu powodują określone problemy artykulacyjne. Dyskusyjne są również stwierdzenia, czy to nieprawidłowości zgryzowe przyczyniają się do powstania wady wymowy, czy też dzieje się odwrotnie. Dokładne poznanie tego zjawiska, zbadanie wspomnianej zależności oraz określenie powiązań między wadami zgryzu a zaburzeniami artykulacji wymaga wielu badań klinicznych.

Artykuł ten jest próbą znalezienia odpowiedzi na pytanie, jakie zaburzenia artykulacji powiązane są z poszczególnymi wadami zgryzu. By lepiej poznać tę zależność, autorki przytaczają opracowania innych badaczy zajmujących się problematyką wad zgryzu i zaburzeń artykulacji, a także opisują badania własne.

Szczegółowe opracowanie tego tematu stanowić będzie zbiór informacji zarówno dla lekarzy ortodontów, jak i dla logopedów. Ich współpraca i kontrola nad prawidłowym rozwojem dziecka jest niezbędna. Skuteczne leczenie ortodontyczne oraz właściwie prowadzona terapia logopedyczna dają znakomite efekty. Należy jednak dokładnie poznać omawiane zjawisko oraz wypracować porozumienie na linii ortodonta-logopeda.

Mamy nadzieję, że artykuł ten przyczyni się do lepszego poznania zależności pomiędzy wadami zgryzu a zaburzeniami artykulacji. Pozwoli przyporządkować konkretne wady wymowy poszczególnym zaburzeniom artykulacji, a także stanie się źródłem wiedzy dla lekarzy ortodontów, logopedów, nauczycieli, rodziców i innych osób zainteresowanych tym tematem. Dzięki temu przyczyni się również do efektywniejszej współpracy specjalistów wyżej wymienionych dziedzin. 


\section{Klasyfikacja wad zgryzu}

Stwierdzenie obecności wady zgryzu niekiedy wydaje się sprawą bardzo prostą, nawet dla laika. Większość zaburzeń artykulacji determinują określone cechy wyglądu twarzy. Jednak głębsza analiza problemu, określenie rodzaju wady zgryzu, wymaga rozleglejszej wiedzy oraz zapoznania się z podstawową klasyfikacją zaburzeń zgryzowych.

Wada zgryzu to nieprawidłowości w budowie i czynności jednego lub kilku elementów zespołu twarzowo-czaszkowego. Zaburzenia dotyczą liczby, położenia, budowy, wielkości zębów, a także tempa ich rozwoju - tzw. wady zębowe (wpływające w różnym stopniu na zgryz) i znacznie rozleglejsze zaburzenia wzajemnego stosunku obu łuków zębowych - tzw. wady zgryzowe. [Konopska 2002a: 86]

Lilianna Konopska [2006: 161] pisze, iż „pod pojęciem rodzaju wad zgryzu rozumie się występowanie w obrębie narządu żucia zmian morfologiczno-czynnościowych, charakteryzujących poszczególne nieprawidłowości zgryzowe”.

W przypadku tyłozgryzów rodzaj nasilenia wady zgryzu rozpatruje się w aspekcie szpary dotylnej, czyli odległości pomiędzy powierzchnią wargową dolnych siekaczy a powierzchnią podniebienną górnych siekaczy.

W przodozgryzach mamy do czynienia ze szparą doprzednią - odległością pomiędzy powierzchniami wargowymi siekaczy obu łuków zębowych. Natomiast w przypadku zgryzów otwartych ocenia się szparę niedozgryzową, czyli przestrzeń pomiędzy brzegami siecznymi siekaczy szczęki górnej i żuchwy.

Istnieje wiele klasyfikacji wad zgryzu. Podstawowy podział rozróżnia wady podłużne i poprzeczne. W skład pierwszej grupy wchodzą: tyłozgryzy, przodozgryzy oraz zgryzy otwarte.

Jak podaje Mirosława Rokitiańska [2004], wady zgryzu dotylne cechuje dotylne ustawienie żuchwy w stosunku do górnego łuku zębowego. Takie ustawienie zębów i szczęk określa się jako II klasę Angle’a. Nieprawidłowości te powstają w wyniku zatrzymania doprzedniego wzrostu dolnego łuku zębów. Wady zgryzu dotylne mogą współwystępować z protruzją, czyli wychyleniem, lub retruzją, czyli przechyleniem zębów siecznych dolnych.

Według Konopskiej [2006] tyłozgryzy charakteryzują się także odstępstwem od normy czynnościowej, polegającym na przewadze mięśni cofających żuchwę oraz nierzadko występującym obniżeniem napięcia mięśniowego górnej wargi. Przy tyłozgryzie obserwuje się zmiany morfologiczne, takie jak brak zwarcia siekaczy górnych i dolnych. Charakterystyczne jest także powstanie poziomej szpary dotylnej między powierzchniami siekaczy obu łuków zębo- 
wych. Obecność tyłozgryzu manifestuje się również w specyficznych rysach twarzy, takich jak: ułożenie profilu w kierunku dotylnym, wydatniejsza bruzda wargowo-bródkowa, cofnięcie lub wywinięcie dolnej wargi połączone z hipotonią wargi górnej.

Doprzednie wady zgryzu, zwane przodozgryzami, polegają na zachodzeniu dolnych siekaczy i kłów na górne zęby przednie. Układ ten stanowi III klasę Angle'a. Obserwuje się tutaj zwykle przewagę czynnościową mięśni wysuwających żuchwę. Stopień nasilenia zmian morfologiczno-czynnościowych w doprzednich wadach zgryzu może być różny w zależności od siły procesów przebiegających w układzie kostno-zębowym [Rokitiańska 2004].

Konopska [2006] pisze o charakterystycznych cechach wyglądu osób z doprzednią wadą zgryzu. W rysach twarzy pacjentów z przodozgryzem zauważamy: swoiste ułożenie profilu w kierunku doprzednim, mniej uwydatnioną bruzdę wargowo-bródkową, a także wysunięcie dolnej wargi, niekiedy również bródki. W przodozgryzach siekacze dolne i górne mogą pozostawać w kontakcie lub powstaje pomiędzy nimi szpara doprzednia.

Jak podaje Rokitiańska [2004], przyczyną powstania przodozgryzu jest przyspieszony wzrost dolnego łuku zębowego bądź też zahamowanie doprzedniego wzrostu łuku zębowego górnego.

Ostatnia grupa zaburzeń zgryzowych w grupie wad podłużnych to zgryzy otwarte, polegające na niedochodzeniu niektórych części szczęki górnej i żuchwy do płaszczyzny zgryzu. „Zgryz otwarty stwierdza się, kiedy między zwartymi łukami zębowymi istnieje po obu stronach przerwa między zębami górnymi i dolnymi” [Rokitiańska 2004: 25].

Brak kontaktu między zębami przeciwstawnymi powoduje powstanie pionowej szpary niedozgryzowej, zwanej infraokluzyjną. Szpara niedozgryzowa może obejmować różne odcinki łuków zębowych w zależności od postaci zgryzu otwartego. Niekiedy, w najtrudniejszych przypadkach, zwierają się tylko ostatnie zęby trzonowe.

W przypadku zgryzów otwartych często mamy do czynienia z trudnościami związanymi z odgryzaniem, żuciem oraz połykaniem. Niekiedy tym wadom zgryzu mogą towarzyszyć obniżone napięcie mięśnia okrężnego ust oraz mięśni twarzy, szczególnie mięśni żujących i mięśni języka. W zgryzach otwartych częściowych nie obserwuje się zwykle zmian w rysach twarzy. Natomiast w przypadku zgryzów otwartych całkowitych charakterystyczne jest wydłużenie szczękowego odcinka twarzy [Konopska 2006].

Druga grupa wad zgryzu to zgryzy poprzeczne, w skład których wchodzą: zgryzy przewieszone, zgryzy krzyżowe, a także boczne przemieszczenia żuchwy. 
Zgryzy krzyżowe cechuje odwrotne zwieranie się zębów obu łuków. Wada ta powiązana jest ze zwężeniem szczęki. Obserwuje się także jednostronne zapadnięcie wargi górnej, uwypuklenie wargi dolnej, obniżenie kąta ust oraz zróżnicowanie konfiguracji mięśni twarzy. Tkanki mięśniowe po stronie przeciwnej do zgryzu krzyżowego są napięte i rozciągnięte. Ponadto warunki zgryzowe nie pozwalają na równoważne ruchy boczne [Rokitiańska 2004].

Dalej Rokitiańska [2004] podaje również, że boczne przemieszczenie żuchwy powoduje zmiany $\mathrm{w}$ rysach twarzy, polegające na odchyleniu, w prawo lub w lewo, od linii środkowej twarzy. Natomiast zgryz przewieszony charakteryzuje się mijaniem się płaszczyzn zgryzowych przy zwarciu obu szczęk. Policzkowe powierzchnie zębów dolnych sąsiadują z podniebiennymi powierzchniami zębów górnych. Łuk górny jest rozszerzony.

Jako główną przyczynę zaburzeń szczękowo-zgryzowo-zębowych Konopska [2006] wymienia czynniki zewnętrzne działające na dziecko w okresie pozapłodowym. Cechy nabyte są rzadziej wymieniane jako powodujące zaburzenia zgryzu. W tej grupie wyszczególnia się przede wszystkim dysfunkcje i parafunkcje układu twarzowo-czaszkowego oraz próchnicę, choroby ogólne organizmu (np. krzywica, alergie, infekcje wirusowo-bakteryjne), a także urazy mechaniczne i termiczne.

\section{Wady zgryzu a zaburzenia artykulacji}

Nieprawidłowy zgryz nie jest bezpośrednią przyczyną wady wymowy, ale bez wątpienia ma znaczny wpływ na poprawność artykulacji. Większość badaczy potwierdza częste występowanie zaburzeń artykulacji u osób z wadami zgryzu. Wady wymowy, przy współwystępujących wadach zgryzu, dotyczą większości badanych przez autorki pacjentów.

Nasilenie występowania wad wymowy u osób z wadami zgryzu oraz częste występowanie wad zgryzu u osób z nieprawidłową artykulacją wskazują, że wady zgryzu mogą być przyczyną wad wymowy lub też, co najmniej, im sprzyjają. [Konopska 2002a: 22]

Z opisanych badań jednoznacznie wynika, że istnieje zależność pomiędzy wadami wymowy a wadami artykulacji. Nie można jednak precyzyjnie określić, czy zaburzenia zgryzowe są powodem występowania nieprawidłowości w wymowie, czy też należy traktować je tylko jako czynnik predysponujący.

Wszelkie nieprawidłowości w budowie anatomicznej narządów mowy, warg, języka, podniebienia, mogą być przyczyną zaburzeń mowy. Nieprawidłowości 
zgryzowe i zębowe utrudniają lub uniemożliwiają poprawną wymowę głosek, przede wszystkim dentalizowanych. Wady zgryzu predysponują do ujawnienia się wad wymowy, ale nie są uważane za główną przyczynę nieprawidłowej artykulacji. [Rokitiańska 2004: 64-65]

Powiązanie wad zgryzu z zaburzeniami artykulacji jest bezsprzeczne. Nie ma jednak porozumienia wśród badaczy co do tego, czy wady zgryzowe przyczyniają się do powstania problemów artykulacyjnych, czy też dzieje się odwrotnie.

Nieprawidłowa wymowa często towarzyszy wadom zgryzu, jednak autorzy nie są zgodni, co jest pierwotną przyczyną - zła wymowa czy wada zgryzu. Zaburzenia prawidłowej wymowy poszczególnych dźwięków pojawiają się najczęściej w zgryzach otwartych, w wadach dotylnych z dużą szparą poziomą oraz wadach poprzednich. [Karłowska, red. 2008: 68]

W swoich pracach Konopska [2002b] potwierdza zależność pomiędzy występowaniem wady zgryzu i obecnością zaburzeń artykulacji. Konkretne wady zgryzu przyczyniają się do występowania określonych rodzajów dyslalii. Zaburzenia artykulacji pojawiają się prawie u wszystkich osób ze stwierdzonym zgryzem otwartym oraz przodozgryzem, a także u ponad $2 / 3$ pacjentów z dotylnymi zaburzeniami zgryzu.

Wielkość szpary dotylnej ma duże znaczenie w przypadku osób z tyłozgryzem. Występowanie wady wymowy zwiększa się zasadniczo wraz z nasileniem dotylnej wady zgryzu. Jak pisze Konopska [2002b], problemy artykulacyjne towarzyszą 54\% pacjentów ze szparą dotylną do $5 \mathrm{~mm}, 70 \%$ ze szparą dotylną pomiędzy 5 a $8 \mathrm{~mm}$ oraz aż 100\% badanych ze szparą dotylną powyżej $8 \mathrm{~mm}$.

W kolejnych swoich pracach Konopska [2002a] potwierdza tezę o związku pomiędzy wadami zgryzu a zaburzeniami artykulacji. W opracowaniu tym autorka zbadała sposób realizacji głosek [t], [d], [n] u osób z nieprawidłowościami zgryzowymi.

Pozanormatywne realizacje polskich fonemów dentalnych występują u większość osób z wadą zgryzu, lecz częściej u osób ze zgryzem otwartym i u osób $\mathrm{z}$ doprzednią wadą zgryzu niż u osób z dotylną wadą zgryzu. [Konopska 2002a: 110]

Ponadto zaburzona artykulacja głosek [t], [d], [n] wzrasta wprost proporcjonalnie do wielkości szpary doprzedniej - w przypadku przodozgryzów - lub dotylnej - w tyłozgryzach. 
Z innych badań Konopskiej [2006] wynika, że wśród 205 osób z wadą zgryzu u 167 stwierdzono wadę wymowy, co stanowi 81\% badanych. Analiza uzyskanych danych nie wskazuje na zależność pomiędzy występowaniem zaburzeń artykulacji a płcią badanych, ich wiekiem, a także obecnością dodatkowych zaburzeń zgryzowych. Badania wykazały również, że spośród 167 osób z wadą wymowy oraz zaburzeniami artykulacji aż 133 nigdy nie było objęte opieką logopedy. Stanowi to aż $80 \%$ osób badanych.

Rokitiańska [2004] podaje, że wady zgryzu dotylne są jedną z częstszych przyczyn wad wymowy. Przy tyłozgryzach miejsce artykulacji głosek denatlizowanych bywa cofnięte, miedzy zębami występuje szpara, która powoduje zmianę brzmienia głosek detalizowanych. Często głoski szeregu syczącego są podobne brzmieniowo do głosek ciszących.

W przypadku przodozgryzów spółgłoski detalizowane często artykułowane są przyzębowo lub międzyzębowo. Jeśli chodzi o zgryzy otwarte, to między zębami obserwuje się szparę pionową, w którą często wpada język podczas artykulacji. Spółgłoski przedniojęzykowo-zębowe bywają realizowane interdentalnie. Notuje się także współwystępowanie, wraz z innymi dysfunkcjami aparatu artykulacyjnego, podniebienia gotyckiego.

Z kolejnych badań Justyny Grudziąż-Sękowskiej [2008] wynika, że wada wymowy występuje u 57\% pacjentów z zaburzeniami zgryzu. Wśród 13 osób z wadami zgryzu dotylnymi 7 miało wady wymowy. Wszystkie osoby ze zgryzem otwartym miały zaburzenia artykulacji. Największe kłopoty artykulacyjne w tej grupie sprawiały głoski: [t], [d], [n] oraz głoski trzech szeregów. Podobnie jak w przypadku zgryzów otwartych w grupie z przodozgryzami wszystkie osoby miały wady wymowy. Najczęściej niepoprawnie artykułowane były głoski szumiące i syczące.

Z badań Grudziąż-Sękowskiej [2008] wynika również, że do powstania wad zgryzu, a co za tym idzie również zaburzeń artykulacji, przyczyniają się: poród cesarskim cięciem, ssanie smoczka powyżej 2. roku życia, karmienie butelką $\mathrm{w}$ niemowlęctwie, ssanie parafunkcyjne oraz przedwczesna utrata zębów mlecznych. W późniejszym okresie znaczące jest niedomykanie warg oraz oddychanie torem ustnym. Notuje się również występowanie zaburzeń zgryzowych i artykulacyjnych rodzinnie, co świadczy o dziedziczeniu tych nieprawidłowości. Dla porównania w grupie dzieci z prawidłowymi warunkami zgryzowymi zaburzenia artykulacji wystąpiły u $22 \%$ badanych.

Zależność wad zgryzu i zaburzeń artykulacji jest zagadaniem istotnym i wartym szerszego opracowania. Istnieje konieczność podjęcia leczenia oraz zrozumienia współwystępujących zależności dla dobra pacjentów. Należy usystematyzować tę wiedzę tak, by terapia logopedyczna oraz leczenie orto- 
dontyczne szły ze sobą w parze. W przypadku stwierdzenia nieprawidłowości zgryzowych logopeda powinien skierować pacjenta na konsultację ortodontyczną. Ponadto zarówno logopeda, jak i ortodonta powinni regularnie kontaktować się ze sobą w celu omówienia postępów czynionych przez dziecko. Każdy ze specjalistów dokonuje bieżącej ewaluacji i informuje o niej drugą stronę. Ortodonta może również zalecić dziecku zestaw ćwiczeń wskazany w leczeniu danej wady wymowy. W ramach początkowej fazy terapii logopedycznej, czyli ćwiczeń usprawniających narządy mowy, logopeda może wykonywać te zadania z dzieckiem. W gestii rodziców leży również przekazywanie informacji, po każdej wizycie u ortodonty lub logopedy, zainteresowanym stronom.

Wady wymowy i wady zgryzu z pewnością mają wspólny mianownik - nieprawidłowe funkcjonowanie narządów artykulacyjnych. Mowa i wady zgryzu mają podłoże w czynnościach fizjologicznych, tak jak: połykanie, ssanie, żucie, oddychanie. Oba te aspekty kształtują prawidłowe lub patologiczne nawyki wymowy i anatomii narządów artykulacyjnych. Z pewnością im szybciej podejmiemy leczenie ortodontyczne i terapię logopedyczną, tym lepiej dla pacjenta. Wzorce nieprawidłowej artykulacji nie są jeszcze tak utrwalone, a w przypadku wady zgryzu potencjał wzrostowy dziecka stwarza możliwość kompensacji nieprawidłowości zgryzowych.

\section{Opis przeprowadzonych badań}

W celu odnalezienia odpowiedzi na pytanie: czy wady zgryzu warunkują powstawanie określonej wady wymowy, autorki artykułu postanowiły przeprowadzić własne badania. Grupę badawczą stanowiło 36 osób (21 chłopców oraz 15 dziewcząt - płeć nie była kryterium poddawanym ocenie). Najmłodsze dziecko w dniu badania miało skończone siedem, a najstarsze 10 lat. W tym wieku rozwój mowy jest już ukończony. W kalendarzu wyrzynania zębów okres od około 8. do około 10. roku życia nazywany jest ,przerwą wyrównawczą". W związku z tym przyjęte zostało, że rozwój mowy i wzrost zgryzu został ukończony. U pacjentów pod uwagę brano wystąpienie wady zgryzu, obecność zaburzenia artykulacyjnego oraz współwystępowanie innych parafunkcji, takich jak: nieprawidłowy tor oddechowy, nieprawidłowy typ połykania czy też słaba pionizacja języka lub jej brak.

Grupa badawcza, która stanowi podstawę badań, została zebrana dzięki uprzejmości i za zgodą dyrekcji oraz logopedów z wielu trójmiejskich placówek, a także w wyniku przeprowadzonych przez autorki diagnoz.

W trakcie prowadzonych w placówkach oświatowych badań opierałyśmy się na udostępnionej dokumentacji. Nie miałyśmy bezpośredniego kontaktu 
z dziećmi. Nie ujawniano nam danych osobowych pacjentów, jedynie ich płeć, wiek, karty badania artykulacyjnego, zaświadczenia od lekarzy specjalistów (laryngolog, ortodonta, pediatra). Z dokumentacją miałyśmy styczność w obecności jednego z pracowników. W klasyfikowaniu wad zgryzu posiłkowałyśmy się takimi właśnie opiniami wystawionymi przez specjalistów (stomatologów, ortodontów). Natomiast zaburzenia artykulacyjne określałyśmy na podstawie diagnoz logopedów pracujących w danej placówce. Posługiwali się oni takimi testami diagnostycznymi, jak Kwestionariusz badania mowy Grażyny Billewicz oraz Sprawdź jak mówię Elżbiety Stecko. Podczas samodzielnych diagnoz również korzystałyśmy z wymienionych wcześniej publikacji, dzięki którym możliwe było zbadanie artykulacji samogłosek i spółgłosek we wszystkich możliwych pozycjach w wyrazie, a także w wybranych grupach spółgłoskowych. Wada zgryzu rozpoznawana była na podstawie zdobytej przez autorki wiedzy i konsultowana z ortodontą lub dentystą.

Na początku badania przeprowadzałyśmy z dzieckiem rozmowę, próbowałyśmy nawiązać z nim kontakt. Obserwowałyśmy jego zachowania językowe podczas spontanicznej wypowiedzi. Jeżeli zauważyłyśmy nienormatywną realizację głoski, odznaczałyśmy ją sobie w karcie badania wymowy i później, podczas badania artykulacji, zwracałyśmy na nią szczególną uwagę. Podobnie było z wadą zgryzu. W karcie zaznaczałyśmy występowanie wady zgryzu i jej charakter. W razie wątpliwości konsultowałyśmy się ze specjalistą.

Jak podałyśmy wyżej, grupa badawcza obejmowała 36 osób, z czego tylko u pięciu nie stwierdzono współwystępowania zaburzeń artykulacyjnych z wadą zgryzu. Okazuje się jednak, że nawet przy poważnych anomaliach zgryzowych: przodozgryzie, tyłozgryzie, zgryzie otwartym czy krzyżowym, wymowa wszystkich głosek może być prawidłowa. Stwierdza się zatem, że zaburzenia artykulacyjne w większości przypadków ( $86 \%$, czyli u 31 osób z grupy badawczej) są skorelowane z występowaniem wady zgryzu, jednak istnieją wyjątki od tej reguły (14\%, czyli u 5 osób z grupy badawczej). Taki wynik pozwala na sformułowanie następującej hipotezy: nieprawidłowości zgryzowe mogą stanowić przyczynę powstawania wad wymowy. Nie jest to jednak regułą.

Podobną opinię wyraziła Konopska [2006]. Wyniki obu badań są dosyć zbieżne. Grupa badawcza Konopskiej była liczniejsza, jednak procentowe wyniki obu badań są podobne. Współwystępowanie wad zgryzu i zaburzeń artykulacyjnych Konopska stwierdziła u $81 \%$ badanych.

Najczęściej występującą wadą zgryzu w grupie badawczej autorek tekstu był zgryz otwarty (33\%). Na drugim miejscu znalazł się przodozgryz (28\%), następnie zgryz krzyżowy (22\%). Najmniej było osób z tyłozgryzem. Stanowiły one zaledwie $17 \%$ całej grupy. Pozioma wada zgryzu - zgryz otwarty - 
występowała u 12 osób i tylko u jednej z nich nie stwierdzono nieprawidłowości artykulacyjnych. Chłopiec ten konsultowany był ortodontycznie, jednak nie podjęto jeszcze leczenia. Z obserwacji i przeprowadzonej przez logopedę diagnozy wynika, że wszystkie głoski znajdują się w normie wymawianiowej. Jedynym niepokojącym objawem było infantylne połykanie.

Tabela. Wptyw wad zgryzu na zaburzenia artykulacji

\begin{tabular}{|l|c|c|}
\multicolumn{1}{|c|}{ Wada zgryzu } & $\begin{array}{c}\text { Liczba badanych, u których } \\
\text { stwierdzono wadę zgryzu }\end{array}$ & $\begin{array}{c}\text { Procent badanych, u których } \\
\text { stwierdzono wadę zgryzu }\end{array}$ \\
\hline Zgryz otwarty & 12 & $33 \%$ \\
\hline Przodozgryz & 10 & $28 \%$ \\
\hline Zgryz krzyżowy & 8 & $22 \%$ \\
Tyłozgryz & 6 & $17 \%$
\end{tabular}

U pozostałych 11 osób dominowały zaburzenia głosek dentalizowanych. Przede wszystkim deformowane były głoski szeregów ciszącego i syczącego. Zniekształcenia te przyjmowały głównie postać seplenienia międzyzębowego. Podobnych obserwacji dokonała Konopska w opracowaniu Jakość wymowy osób z wada zgryzu, które ukazało się w tomie 31 czasopisma „Logopedia”, wydanym przez Polski Związek Logopedów w 2002 roku. Według autorki międzyzębowość stwierdzono aż u 77\% osób ze zgryzem otwartym. U większości osób zaburzane były również głoski [t], [d], [n], co w połączeniu z nienormatywną realizacją spółgłosek trzech szeregów daje postać sygmatyzmu interdentalnego wielorakiego.

Szereg szumiący u dwóch pacjentów artykułowany był dorsalnie. Bardzo często zaburzeniu ulegała również głoska $[\mathrm{r}]$. U jednych występował pararotacyzm [r] : [1], przy czym głoska [1] realizowana była międzyzębowo. Inni artykułowali głoskę [r] międzyzębowo. Zdarzały się również parasygmatyzmy w obrębie głosek szumiących i syczących.

Jak pokazują wyniki badań własnych, około $80 \%$ pacjentów ze zgryzem otwartym miało również inne dysfunkcje w postaci połykania infantylnego. Język w trakcie tego odruchu wsuwa się pomiędzy zęby i wargi. Tylko dwie spośród 12 osób nie miały tego problemu. Dodatkową niesprawnością była słaba pionizacja języka. W związku z tym można wysnuć wniosek, że wady zgryzu powodują zaburzenie napięcia mięśniowego lub współwystępują z nim oraz z brakiem pionizacji języka. 
Drugą najczęściej występującą wadą zgryzu w opisywanej grupie badawczej jest przodozgryz. Stwierdzony został u $28 \%$ badanych. Tutaj również tylko u jednej osoby nie współwystępowały zaburzenia artykulacji. U pozostałych dziewięciu osób rozpoznano m.in. międzyzębową realizację głosek: trzech szeregów, [t], [d], [n], oraz [r] - u jednego pacjenta. Dwoje spośród badanych dzieci realizowało błędnie głoski trzech szeregów: w sposób międzyzębowy boczny i przyzębowy. Połowa grupy miała dodatkowe nieprawidłowości w funkcjonowaniu artykulatorów: zespół oddechowo-połykowy lub wyizolowany dziecięcy typ połykania, słabą pionizację języka.

Kolejną podgrupę przedstawiają pacjenci ze zgryzem krzyżowym. Stanowią oni $22 \%$ całej grupy badawczej. Dwóch pacjentów nie miało problemów z poprawną realizacją głosek. U trzech badanych można było zauważyć nieprawidłową pracę języka podczas realizacji głosek trzech szeregów. W trakcie artykulacji język układał się asymetrycznie, strumień powietrza wydostawał się bokiem (sygmatyzm boczny). W miejscu jego przepływu wargi rozwierały się. Jeden z tych pacjentów miał odmianę boczną międzyzębową seplenienia (język wchodził pomiędzy zęby przedtrzonowe).

Tylko u jednego z badanych ze zgryzem krzyżowym utrzymywała się dorsalna wymowa głosek [sz], [cz]. U kolejnych dwóch zaburzenia artykulacyjne dotyczyły nieustabilizowanej wymowy głosek trzech szeregów (parasygmatyzm).

W badanej grupie najrzadziej, wśród nieprawidłowości zgryzowych, pojawiał się tyłozgryz. Grupę tę prezentowało sześć osób, z czego u jednej nie zdiagnozowałyśmy wady wymowy. U pozostałych dominowała substytucja głosek szumiących na syczące oraz pararotacyzm [r] : [1]. U jednej osoby zdiagnozowany został rotacyzm gardłowy. Inna substytuowała głoski bezdźwięczne [k], [t] na ich dźwięczne odpowiedniki. Ponadto jeden z chłopców realizował głoski [s], [z], [c], [dz] międzyzębowo. U niego dodatkowo występowały zaburzenia słuchu fonematycznego oraz zespół oddechowo-połykowy.

U pacjentów z przodozgryzem dominowała interdentalna realizacja głosek dentalizowanych oraz [1]. Podobna tendencja utrzymywała się u osób ze zgryzem otwartym. Do podobnych wniosków dochodzi w swojej pracy badawczej Konopska. Zauważa ona, że wadliwe realizacje głosek dentalizowanych występują głównie w zgryzach otwartych oraz przodozgryzach [Konopska 2002a]. W obu przypadkach należy również zwrócić uwagę na problemy z prawidłową realizacją głoski [r]. W pierwszej grupie bardzo często występował rotacyzm, ale przyjmował on różne typy deformacyjne: jednouderzeniowy, gardłowy, interdentalny. Natomiast w grupie drugiej była to najczęściej forma substytucji [r] na [1]. 
Międzyzębowa realizacja głosek, głównie dwóch szeregów, szumiącego i syczącego, często pojawiała się u pacjentów ze zgryzem krzyżowym. Niekiedy przyjmowała ona postać seplenienia międzyzębowego bocznego. Natomiast przy tyłozgryzach na plan pierwszy wysuwa się skłonność do parasygmatyzmu (szumiące : syczące) oraz pararotacyzmu $[\mathrm{r}]:[1 / \mathrm{j}]$.

Dodatkowo, niezależnie od typu wady zgryzu, można stwierdzić olbrzymią tendencję do infantylnego połykania. U ponad połowy badanych (56\%) stwierdzony został nieprawidłowy typ połykania. U części pacjentów tym objawom towarzyszył również niepoprawny, ustny tor oddechowy.

Podsumowując, każda wada zgryzu może wywołać określone zaburzenia artykulacyjne. Nie stanowi to jednak reguły. Nawet przy bardzo poważnej wadzie zgryzu istnieje szansa na prawidłową realizację głosek. W tym przypadku olbrzymią rolę odgrywają możliwości kompensacyjne, prawidłowa praca mięśni czy też prawidłowe wzorce wymawianiowe. Ponadto, porównując wyniki badań, można domniemać, która $\mathrm{z}$ wad wymowy będzie skorelowana $\mathrm{z}$ istniejącą wadą zgryzu. Należy jednak pamiętać, że są to tylko tendencje, od których istnieją wyjątki.

\section{Zakończenie}

Celem przeprowadzonych badań było przybliżenie tematyki wad zgryzu w aspekcie logopedycznym, a przede wszystkim zbadanie, jaki wpływ na zaburzenia artykulacji ma występowanie wady zgryzu. Temat został przedstawiony w wymiarze praktycznym. Poza teoretycznymi wyznacznikami zaburzeń zgryzu wskazane zostały najczęściej współwystępujące z daną wadą zgryzu wady wymowy oraz cechy morfologiczne twarzy.

W wyniku przeprowadzonych badań udało się ustalić, że określone wady zgryzu mogą powodować powstawanie konkretnych zaburzeń artykulacyjnych, jednak nie zawsze istnienie nieprawidłowości zgryzowych wywołuje konkretną wadę wymowy. Są to tylko tendencje. Istnieją osoby, które mimo wad anatomicznych realizują wszystkie głoski w sposób normatywny.

W trakcie badań zauważono również, że wpływ na nieprawidłową artykulację ma także nasilenie wady zgryzu, np. w zgryzach otwartych wielkość szpary niedozgryzowej. Jednak jest temat to wymagający szerszej analizy i bardziej szczegółowych badań. 


\section{Bibliografia}

Karłowska Irena, red. (2008), Zarys współczesnej ortodoncji. Podręcznik dla studentów i lekarzy dentystów, Wydawnictwo Lekarskie PWZL, Warszawa.

Konopska Lilianna (2002a), Jakość realizacji polskich fonemów dentalnych u osób z wada zgryzu, „Logopedia”, t. 30, s. 105-114.

Konopska Lilianna (2002b), Jakość wymowy osób z wada zgryzu, „Logopedia”, t. 31, s. $157-199$.

Konopska Lilianna (2006), Wymowa osób z wada zgryzu, Madia Druk, Szczecin.

Rokitiańska Mirosława (2004), Podstawy ortodoncji dla logopedów, Wydawnictwo Akademii Bydgoskiej im. Kazimierza Wielkiego, Bydgoszcz.

Sękowska-Grudziąż Justyna (2008), Współzależność wad wymowy i wad zgryzu. Badanie własne w grupie dzieci 7-8 letnich, „Logopeda”, nr 6, s. 7-31, http://www. logopeda.org.pl/resources/pliki/69_logopeda_nr_6.pdf, [dostęp: 1 marca 2015].

Patrycja Lisiecka, Dagmara Piątkowska

\section{The impact of malocclusions on phonation disorders}

This article presents a review of the research conducted to date into the coexistence of malocclusions and phonation disorders, as well as the results of research conducted by the authors of the article. It is an attempt at providing answers to the following questions: are phonation disorders related to specific malocclusions, what specific phonation disorders accompany specific occlusal problems, does a single problem condition another occlusal problem?

Detailed study of this subject will provide a concise compilation of knowledge for experts in many areas, including speech-language pathology, orthodontics, paediatrics, otolaryngology and phoniatrics. The article presents a specific approach to occlusion, namely from the speech-language pathology point of view. The authors have associated phonation disorders with specific malocclusions.

Numerous clinical trials are necessary to investigate this phenomenon, to research the above mentioned dependence and identifying the relations between malocclusions and phonation disorders. The article presents the results of the research carried out by the authors together with results of surveys undertaken by professionals dealing with the impact of malocclusions on phonation disorders over the years.

KEYwORDS: $\quad$ speech-language pathology; speech-language pathologist; malocclusion; phonation disorders; underbite; overbite; open bite; orthodontist; teeth; lower jaw; alveolar ridge; incisors; dyslalia; morphological change. 
mgr Patrycja Lisiecka - Gimnazjum nr 20 w Gdańsku; zainteresowania naukowe: kształtowanie się języka dziecka, zaburzenia artykulacji, wady zgryzu, specyficzne zaburzenie językowe SLI, opóźniony rozwój mowy, kompetencje komunikacyjne osób niepełnosprawnych intelektualnie, profilaktyka logopedyczna.

mgr Dagmara Piątkowska - PSOUU KOŁO w Świdnicy Ośrodek Rehabilitacyjno-Edukacyjno-Wychowawczy; zainteresowania naukowe: rozwój mowy, zaburzenia artykulacyjne, wady zgryzu i zaburzenia w budowie anatomicznej aparatu artykulacyjnego, kompetencje komunikacyjne osób z niepełnosprawnością intelektualną. 
